\section{Regards sur l'économie allemande}

Bulletin économique du CIRAC

$97 \mid 2010$

Varia

\title{
Compétitivité des regions
}

KARLSSON Charlie, JOHANSSON Börje, STOUGH Roger R. (eds), Innovation, Agglomeration and Regional Competition

\section{(2) OpenEdition}

\section{Journals}

Édition électronique

URL : http://journals.openedition.org/rea/4157

DOI : $10.4000 /$ rea. 4157

ISBN : 978-2-8218-0890-4

ISSN : 1965-0787

Éditeur

CIRAC

\section{Édition imprimée}

Date de publication : 1 juillet 2010

Pagination : 35

ISSN : 1156-8992

Référence électronique

"Compétitivité des regions », Regards sur l'économie allemande [En ligne], 97 | juillet 2010, mis en ligne le 13 juillet 2010, consulté le 22 septembre 2020. URL : http://journals.openedition.org/rea/4157 ;

DOI : https://doi.org/10.4000/rea.4157

Ce document a été généré automatiquement le 22 septembre 2020.

(c) CIRAC 


\section{Compétitivité des regions}

KARLSSON Charlie, JOHANSSON Börje, STOUGH Roger R. (eds), Innovation, Agglomeration and Regional Competition

\section{RÉFÉRENCE}

KARLSSON Charlie, JOHANSSON Börje, STOUGH Roger R. (eds), Innovation,

Agglomeration and Regional Competition, New Horizons in Regional Science, Edward Elgar Publishing Limited, Cheltenham, 2009, 405 p.

1 Dans un contexte économique décentralisé et globalisé, les régions occupent aujourd'hui une place de choix en termes de compétitivité et d'innovation. Conçu autour d'éléments théoriques et empiriques, le présent ouvrage met en évidence les modes de coopération et l'émulation interrégionale. Et permet d'en comprendre les incidences sur l'allocation des ressources, la localisation des activités économiques et la distribution des revenus. Un éclairage précis et actuel, à destination des étudiants, chercheurs et décideurs politiques. (sh) 